ISSN: 2231-3354

Received on: 19-07-2012

Revised on: 09-08-2012

Accepted on: 16-08-2012

DO: 10.7324/J APS.2012.2823

S. Shahitha and K. Poomima Department of Microbiology, Muthayammal College of Arts and Science, Rasipuram.

For Correspondence

\section{Enhanced Production of Prodigiosin Production in Serratia Marcescens}

\author{
S. Shahitha and K. Poomima
}

\begin{abstract}
Prodigiosins, a family of natural red pigments characterized by a common Pyrrolylpyrromethane skeleton are produced by various bacteria that first characterized from Serratia marcescens, Pseudomonas magneslorubra, Vibrio psychroerythrous etc. In this study, different media like nutrient broth, peptone glycerol broth, powdered peanut seed broth and powdered sesame seed broth, sugar substrates (maltose and glucose) and different oils like peanut oil, sesame oil, coconut oil at different temperature were used to study the prodigiosin production in Serratia marcescens. The highest pigment production was observed in powdered peanut seed broth $(37.6 \mathrm{mg} / \mathrm{ml})$ and powdered sesame seed broth $(16.5 \mathrm{mg} / \mathrm{ml})$ when compared to the use of nutrient broth $(0.51 \mathrm{mg} / \mathrm{ml})$ and peptone glycerol broth $(0.3 \mathrm{mg} / \mathrm{ml})$ at $28^{\circ} \mathrm{c}$, Nutrient broth with maltose yielded $(1.82 \mathrm{mg} / \mathrm{ml})$ of prodigiosin. Among different oils, peanut oil showed high pigment production $(2.72 \mathrm{mg} / \mathrm{ml})$ and these pigment can be used to dye cotton which showed good color tone.
\end{abstract}

Keywords: Prodigiosin, Serratia marcescens, Pyrrolylpyrromethane.,peanut seed.

\section{INTRODUCTION}

Serratia spp are gram negative bacteria classified in the large family of Enterobactericeae and these bacteria grow well on standard media and produce a red to dark pigment that aids in its identification and the red color pigment is so called prodigiosin (Samrot et al., 2011). Prodigiosin is a multifaceted secondary metabolites. The prodigiosin group of natural product is a family of tripyrrole red pigment that contains a common 4-methoxy 2,2 bipyrrole ring system. The biosynthesis of the pigment is a bifurcated process in which mono and bipyrrole precursors are synthesized separately and then assembled to form prodigiosin (Boger et al., 1988). Many types of differential and selective media have been developed for the isolation and testing of Serratia spp. Capryllate thallous (CT) agar contains caprylate as a carbon source for Serratia spp and thallous salts as inhibitors for other organism (Staunton et al., 1997) and CT is the best at selecting Serratia spp. The regular liquid media currently being used for prodigiosin biosynthesis are nutrient broth (Pyrce et al., 2000) peptone glycerol broth (Hiroaki et al., 1996) and production medium. Prodigiosin is a promising drug owing to its reported characteristics of having antibacterial, anti-fungal, anti-neoplastic, anti-proliferative, anti-oxidant and anti-malarial activity. (Anita et al., 2006). 
At present, fabrics are dyed mainly with synthetic pigments. However, natural pigments are still valuable because of their natural color tones (Shirata et al., 1999). Natural pigments can be obtained from two major sources, plants and microorganism (Mizukami et al., 1978). Using plants in producing colorants is not environmentally friendly and sustainable due to the large amount of biomasses produced. Recently there has been increasing interest in using microorganism as a color source, because the production of pigment from microorganisms, easy and fast growth in the cheap culture medium, independence from weather conditions and colors of different shades. Hence, microbial pigment production is now one of the emerging fields of research to demonstrate its potential for various industrial applications (Parekh et al., 2000).

\section{MATERIALS AND METHODS}

Soil samples were collected, serially diluted and plated on nutrient agar plates. Red pigmented colonies were isolated from the plates after incubation and stored at $4^{\circ} \mathrm{c}$. The isolated colonies were identified based on bergey's classification of determinative bacteriology.

Effect of Different Media on Pigment Production at Different Temperature at $28^{\circ} \mathrm{C}, 30^{\circ} \mathrm{C}, 37^{\circ} \mathrm{C}$

Fresh pigmented culture $(5 \%)$ was inoculated in $50 \mathrm{ml}$ of nutrient broth, $50 \mathrm{ml}$ of peptone glycerol broth, $2 \%$ powdered sesame seed in $50 \mathrm{ml}$ of distilled water, $2 \%$ peanut seed in $50 \mathrm{ml}$ of distilled water. The $\mathrm{pH}$ of all the media maintained at 7.0 and incubated at different temperature $28^{\circ} \mathrm{c}, 30^{\circ} \mathrm{c}, 37^{\circ} \mathrm{c}$ for $48 \mathrm{hrs}$.

Effect of Sugars on Prodigiosin Production in Nutrient Broth at $28^{\circ} \mathrm{C}, 30^{\circ} \mathrm{C}$ and $37^{\circ} \mathrm{C}$

Nutrient broth with $(0.5 \%)$ maltose and nutrient broth with $(0.5 \%)$ glucose were taken. The $\mathrm{pH}$ of the broth was adjusted to 7.0. Fresh pigmented (5\%) culture was added to each of the broth and incubated at $28^{\circ} \mathrm{C}, 30^{\circ} \mathrm{C}, 37^{\circ} \mathrm{C}$ for $48 \mathrm{hrs}$.

Effect of Different Oil Substrates on Piment Production at $28^{\circ} \mathrm{C}, 30^{\circ} \mathrm{C}, 37^{\circ} \mathrm{C}$

The effect of different oil substrates on pigment production were tested by adding $2 \%$ sesame oil in $50 \mathrm{ml}$ of distilled water, $2 \%$ peanut oil in $50 \mathrm{ml}$ of distilled water and $2 \%$ coconut oil in $50 \mathrm{ml}$ of distilled water. The $\mathrm{pH}$ was adjusted to 7.0.Fresh pigmented $(5 \%)$ culture was added in to each of the broth and incubated at $28{ }^{\mathrm{O}} \mathrm{C}, 30^{\circ} \mathrm{C}, 37^{\circ} \mathrm{C}$ for $48 \mathrm{hrs}$.

\section{Extraction of Prodigiosin from Culture Broth}

The pigment was extracted by adding 4 volumes of acetone to culture broth. The acetone mixture was shaken for $3 \mathrm{hrs}$ at room temperature, then centrifuged. The sediment cell debris was washed twice by resuspended in $50 \mathrm{ml}$ of acetone shaking for $30 \mathrm{~min}$ and centrifuging. The washings were combined with the supernatant from the original centrifugation and the solution was filtered. Pigment was extracted from small portions of the filtrate by mixing thoroughly with 1 volume of acetone solution with 2 volumes of petroleum ether in a separatory funnel. The acetone was removed by adding 10 volumes to the funnel then drawing off acetone water phase. This procedure was reported until the entire filtrate was extracted and the pigment, the petroleum ether was evaporated in vacuum at $30^{\circ} \mathrm{c}$ to $40^{\circ} \mathrm{c}$.

\section{Potential Effect of Prodigiosin on Dyeing}

The bacterial culture broth were taken in a beaker and boiled after the addition several times of more than 10 times the amount of water. After bringing the solution to boiling, the cotton cloth to be dyed was dipped in it and the bath was allowed to simmer for about $20 \mathrm{~min}$. The cotton was then washed with water and dried in the shade.

\section{RESULTS}

Among 10 soil samples, Red pigmented colonies were isolated from 3 soil samples. The isolated colonies were identified based on their morphology and biochemical characteristics. The isolates were confirmed as Serratia marcescens.

\section{Effect of Different Media on Pigment Production at Different Temperature at $28^{\circ} \mathrm{C}, 30^{\circ} \mathrm{C}, 37^{\circ} \mathrm{C}$}

The pigment production was observed at $28{ }^{\circ} \mathrm{c}$ in all media were used except peptone glycerol broth at $30{ }^{\circ} \mathrm{C}$. The highest pigment production was observed in powdered peanut seed broth $(37.6 \mathrm{mg} / \mathrm{ml}$ ) followed by powdered sesame seed broth $(16.5 \mathrm{mg} / \mathrm{ml})$ when compared to nutrient broth $(0.51 \mathrm{mg} / \mathrm{ml})$ and peptone glycerol broth $(0.30 \mathrm{mg} / \mathrm{ml})$ at $28 \quad{ }^{\circ} \mathrm{C}$. (shown in table-1).

Table. 1: Effect Of Different Media, Sugars, Different Oils On Pigment Production At Different Temperature At $28^{\circ} \mathrm{c}, 30^{\circ} \mathrm{c}, 37^{\circ} \mathrm{c}$.

\begin{tabular}{lccc}
\hline \multicolumn{1}{c}{ MEDIA USED } & \multicolumn{2}{c}{ RESULTS $(\mathbf{m g} / \mathbf{m l})$} \\
& $\mathbf{2 8}^{\mathbf{0}} \mathbf{C}$ & $\mathbf{3 0}^{\mathbf{0}} \mathbf{C}$ & $\mathbf{3 7}^{\mathbf{}} \mathbf{C}$ \\
\hline Nutrient broth & 0.51 & 0.35 & 0.11 \\
Peptone glycerol broth & 0.30 & 0.12 & 0.1 \\
Powdered peanut seed broth & 37.6 & 24.9 & 1.37 \\
Powdered sesame seed broth & 16.5 & 9.1 & 0.3 \\
\hline
\end{tabular}

Effect of Sugars on Prodigiosin Production in Nutrient Broth At $28^{\circ} \mathrm{C}, 30^{\circ} \mathrm{C}, 37^{\circ} \mathrm{C}$

The pigment was high in nutrient broth with maltose $(1.82$ $\mathrm{mg} / \mathrm{ml})$ followed by nutrient broth with glucose $(1.67 \mathrm{mg} / \mathrm{ml})$ when compared to nutrient broth without sugars (shown in table-2).

Table. 2: Effect of Sugars on Pigment Production In Nutrient Broth.

\begin{tabular}{lccc}
$\begin{array}{l}\text { Nutrient broth with } 0.5 \% \\
\text { maltose }\end{array}$ & 1.82 & 0.73 & 0.10 \\
$\begin{array}{l}\text { Nutrient broth with } \\
\text { 0.5\%glucose }\end{array}$ & 1.67 & 0.25 & 0.1 \\
\hline
\end{tabular}

Effect of Different Oil Substrates on Pigment Production At $28^{\circ} \mathrm{C}, 30^{\circ} \mathrm{C}, 37^{\circ} \mathrm{C}$

The prodigiosin production was higher in peanut oil $(2.72$ $\mathrm{mg} / \mathrm{ml})$ than coconut oil $(1.39 \mathrm{mg} / \mathrm{ml})$ and sesame oil $(0.66 \mathrm{mg} / \mathrm{ml})$ at $28{ }^{\circ} \mathrm{C}$, and it was decreased at $30^{\circ} \mathrm{C}, 37^{\circ} \mathrm{C}$ (Shown in table-3). 
Table. 3: Effect Of Different Oil Substrates On Pigment Production.

$\begin{array}{lccc}\text { Peanut oil broth } & 2.72 & 0.54 & 0.1 \\ \text { Sesame oil broth } & 0.66 & 1.01 & 0.1 \\ \text { Coconut oil broth } & 1.39 & 0.02 & 0.162\end{array}$

\section{POTENTIAL EFFECT OF PRODIGIOSIN ON DYEING}

The prodigiosin dyed cotton showed good colour tone but it has less stability.

\section{DISCUSSION}

Prodigiosin, a secondary metabolite produced by Serratia marcescens (Samrot et al., 2011). who reported that the optimal condition for pigment production found in nutrient broth at $28^{\circ} \mathrm{c}$, and $\mathrm{pH}$ 7.(Giri et al., 2004) reported that powdered peanut broth had supported better growth of Serratia marcescens and higher yield of prodigiosin when compared with the existing nutrient broth and peptone glycerol broth and they have concluded that the fatty acid form of carbon source has play in enhanced cell growth and prodigiosin production. According to (kim et al., 1998). oil gave a better yield over the various carbon (not fatty acid containing seeds) and nitrogen sources tested. The bonded fatty acids as carbon source are less accessible by Serratia marcescens. In this study, The pigment production was higher in powdered peanut seed broth and powdered sesame broth than nutrient broth and peptone glycerol broth at $28{ }^{\circ} \mathrm{c}$. There was no prodigiosin production in nutrient broth at $37^{\circ} \mathrm{c}$ but peanut broth, sesame broth supported the prodigiosin production up to $37^{\circ} \mathrm{c}$. The addition of sugars only showed slight enhancement of prodigiosin production in nutrient broth $(1.82 \mathrm{mg} / \mathrm{ml})$. From this, maltose act as a better source of substrate in enhancing pigment production in nutrient broth. Among 3 different oils, the peanut oil showed high pigment production $(2.72 \mathrm{mg} / \mathrm{ml})$ followed by coconut oil $(1.39 \mathrm{mg} / \mathrm{ml})$, sesame oil $(0.66 \mathrm{mg} / \mathrm{ml})$. From this, peanut oil, coconut oil and sesame oil as substrate were more efficient in inducing pigment production than nutrient broth or peptone glycerol broth.

Biosynthesis of colorants for textile applications has attracted increased interest in recent years. Nature produces many biocolorants from various resources including plants, animals, and microorganisms, which are possible alternatives to synthetic dyes and pigments currently employed. (Mapari et al., 2005).Some natural colorants, especially anthraquinone type compounds, have shown remarkable antibacterial activity in addition to providing bright colour (Frandsen et al., 2006). which could serve as functional dyes in producing colored antimicrobial textiles. (Alihosseini et al., 2008) characterized the bright red pigment prodigiosin from Vibrio spp. and suggested that it could be used to dye many fibers including wool, nylon, acrylics and silk. The red pigment prodigiosin extracted from the Serratia marcescens and applied on cotton, which showed good colour tone and did not change the color in washing but it was sensitive to sunlight drying.

\section{CONCLUSION}

Based on the study, it was concluded that the powdered peanut seed broth was found to be the best and cheapest medium for prodigiosin production in Serratia marcescens. as well as peanut oil than nutrient broth. The dyed cotton showed good color tone therefore, the prodigiosin pigment can be suggested for dyeing the textiles.

\section{REFERENCES}

Alihosseini, F. Ju, K.S. Lango, J. Hammock, B.D and Sun, G. Antibacterial colorants characterization of prodigioginines and their applications on textile materials. Biotechnol Prong 2004; 24: 742-747.

Anita Khanafari Mahnaz Assadi and Fatemeh Ahmadi Fakhr. Review of Prodigiosin, Pigmentation In Serratia marcescens. Journal Of Biological Science 2006;6 (1): 1 - 13.

Boger, P.C and Patel, M. Total Synthesis Of Prodigiosin , Prodigiosene And Desmethoxy Prodigiosin: Diel-Alder Reactions Of Heterocyclic Azidenes and Development Of An Effective Palladium (11)Promoted 2-2- Bipyrrole Coupling Procedure. J.Org.Chem 1988; 53 : $1405-1415$.

Frandsen, R.J.N. Nielsen, N.J. Maolanon, N. Sorensen, J.C. Oisson, S. Nielsen, J. and Giese H. The biosynthetic pathway for aurofusarin in Fusarium graminearum reveals a close link between the naphthoquinones and naphthpyrones. Mol Microbial 2006; 61:1069-1080.

Giri, V. Nandini Anand kumar, Geetha Muthukumaran and Gautam Pennathur. A Noval Medium For The Enhanced Cell Growth And Production Of Prodigiosin From Serratia marcescens Isolated From Soil. BMC Microbio $2004 ; 14$ : 11

Hiroaki, M. Hiroyuki, A. Masakatsu, F. Takeji, S. and Teisuya, T. Industrial production of optically active intermediate in the synthesis of dialtizem with lipase. Seibutsu Kogaku 1996;74:273-288.

Mapari, S.A.S. Nielsen, K.F. Larsen, T.O. Frisvad, J.C. Meyer, A.S. and Thrane, U. Exploring fungal biodiversity for the production for the production of water soluble pigments as potential natural food colorants. Curr Opin Biotechnol 2005;16:109-238.

Mizukami, H. Konoshima, M. and Tabata, M. Variation in pigment production in Lithospermum erythrorhizon callus cultures.phytochem, 17:9-97.

Kim C.H., Sung-Ho K., Suk-In K.(1998b).Isolation and characteristics of prodigiosin like red pigment produced by Serratia sp.KH-95.Korean J Appl Microbial Biotechnol 1978;26:283-289.

Pryce, L.H. and Terry, F.W. Spectrophotometric Assay of Gene Expression: Serratia marcescens Pigmentation. Bioscience 2000;26:3-13.

Samrot, V. Chadana, K. Senthil kumar, P and Narendra kumar, G. Optimization of prodigiosin production by Serratia marcescens SU-10 and evalution of its bioactivity. International research journal of Biotechnology.2011; Vol 2(5).pp,128-133.

Shirata, A. Tsukamoto, P. Yasui, H. Hata, T. Hayasaka, S. Kojima, A. and Kato, H. Isolation of bacteria producing bluish purple pigment and use for dyeing. JARQ 2000;34,131-140.

Staunton, J. and Wilkinson, B. Biosynthesis of Erythromycin and Rapamycin. Chem Rev 1997;97:2611-2629. 